\title{
Microclimate and Columnar Apple Tree Performance within Insect- exclusionary Cages
}

\author{
D.S. Lawson \\ Department of Entomology, New York State Agricultural Experiment Station, \\ Geneva, NY 14456-0462
}

S.K. Brown

Department of Horticultural Science, New York State Agricultural Experiment Station, Geneva, NY 14456-0462

\section{J.P. Nyrop and W.H. Reissig \\ Department of Entomology, New York State Agricultural Experiment Station, Geneva, NY 14456-0462 \\ Additional index words. microenvironment, Malus domestica, protected cultivation, mesh cages, arthropods}

\begin{abstract}
A barrier system for pest control consisting of insect-exclusionary cages covered with three types of mesh material was placed over columnar apple (Malus domestica Borkh.) trees. This system has been shown to provide arthropod control equivalent to insecticides. Light intensity, evaporation, and air and soil temperature were reduced inside the cages. Shoot elongation of columnar apple trees grown inside insect-exclusionary cages was significantly greater than that of trees grown outside the cages. However, this increased shoot growth was not due to etiolation. Tree performance was unaffected by insect-exclusionary cages. Fruit set and fruit soluble solids concentration were not reduced by the cages; however, fruit color intensity was reduced as the degree of shading from the mesh increased. These findings, in conjunction with high levels of arthropod control by insect-exclusionary cages, may allow insect-exclusionary cages to be used for evaluating integrated pest management thresholds, predator-prey relationships, and apple production without insecticides.
\end{abstract}

This study reports on microenvironmental changes and tree performance in a physical barrier system (insect-exclusionary cages) placed around apple trees for pest control. Until recently, the use of insect-exclusionary cages to reduce arthropod colonization of apple trees has not been feasible due to large tree size. However, the availability of a new apple tree form provided the impetus to test a barrier pest control system. Columnar-form apple trees having compact growth habits characterized by reduced internode length, limited branching, numerous fruit spurs, and stiff upright growth (Fig. 1) were used in this study (Fisher, 1970; Looney and Lane, 1984). These trees

Received for publication 20 Aug. 1993. Accepted for publication 20 Apr. 1994. We thank David Terry and Stephen Valerio for their technical assistance, Ian Merwin for his critical review of this manuscript, John Barnard for his assistance in data analysis, and Alan Lakso for his insightful suggestions about methods for measuring changes in microclimate and tree performance inside insect-exclusionary cages. The use of trade names in this publication does not imply endorsement by Cornell Univ. of the products named, nor criticism of similar ones not mentioned. Partial funding for this research is from the U.S. Dept. of Agriculture regional integrated management of apple pests in the northeast. The cost of publishing this paper was defrayed in part by the payment of page charges. Under postal regulations, this paper therefore must be hereby marked advertisement solely to indicate this fact. allowed insect-exclusionary cages to be developed on a much smaller scale than that required for dwarf or standard trees. Insectexclusionary cages made from metal frames covered with various mesh materials and placed around columnar trees have significantly reduced damage from direct and indirect apple pests (Lawson et al., 1994).

A pest-control system with low-chemical input is desirable for apple production and research. Apples are one of the most heavily sprayed agricultural commodities produced in the United States because more than 500 species of arthropods feed on apple (Croft, 1978; Reissig et al., 1984). Any system that can reduce pesticide use from apples while still maintaining fruit quality will provide new insight into low-chemical input production. From a research standpoint, the feasibility of studying naturally occurring predators and parasitoids of phytophagous apple pests in an orchard setting has usually been hampered by the use of insecticides to control direct fruitfeeding insects (Collyer, 1958; Croft, 1978; Herbert and Sanford, 1969; Sanford and Herbert, 1967). A system that uses nonchemical means to exclude all direct fruit-feeding insects, without excluding foliage-feeding or predatory arthropods, could foster biological control and allow the production of apples without the use of insecticides. As agricultural production moves away from exclusive reli- ance on pesticides toward an increasing reliance on beneficial organisms for pest control, systems that offer opportunities to examine predator-prey relationships will be valuable.

Columnar trees with resistance to several diseases are being developed at Cornell Univ.'s New York State Agricultural Experiment Station in Geneva. Because these trees require minimal pruning, are resistant to several diseases, and can be protected from arthropod damage by insect-exclusionary cages, a truly low-chemical input and sustainable method of apple production could be developed for use by amateur orchardists and in small-scale nonchemical fruit production systems.

The use of insect-exclusionary cages, whether for research purposes or apple production, will require adequate tree performance within the enclosure. Insect-exclusionary cages that adversely affect tree performance would not be acceptable. Our research objective was to determine the effect of insect-exclusionary cages on the microclimate surrounding the trees and the resultant effect on tree performance.

\section{Materials and Methods}

Two insect-exclusionary cage designs were evaluated. Large cages with arched tops were constructed of 9.5 -mm-diameter steel rods and were $4.5 \mathrm{~m}$ long $\times 0.91 \mathrm{~m}$ wide at the base $\times 1.8 \mathrm{~m}$ high (Fig. 2 ). There were six treatments. Three consisted of the following mesh types placed over a cage: 1 ) fine ("No-seeum," white polyester material, pore size $1.0 \times 0.13$ $\mathrm{mm}$; The Baslon Hercules Group, Providence, R.I.); 2) medium ("Lumite" style $18 \times 14$ amber, pore size $1.0 \times 1.5 \mathrm{~mm}$; Chicopee, Gainesville, Ga.); 3) large ("DUR-30", white polyester, pore size $3.0 \times 3.0 \mathrm{~mm}$; Apex Mills Corp., Inwood, N.Y.), fully enclosing the trees. The fourth treatment consisted of the medium mesh with the top open (medium-O). In the remaining two treatments, the trees were not covered, one group receiving insecticides and the other none. Cages were arranged in a randomized complete-block design with two replicates of each treatment in each of three blocks.

'Starkspur Compact Mac'/MM.106 apple trees (Stark Bros. Nursery, Louisiana, Miss.) that were not disease resistant were used in this study because adequate quantities of diseaseresistant columnar trees could not be obtained. These trees were planted $0.91 \mathrm{~m}$ apart in the north-south direction in staggered double rows in each of the three blocks on 18 Apr. 1991. The cages and mesh coverings were installed over the trees before budbreak, and the mesh coverings were removed after leaf fall during 1991 and 1992.

In Fall 1990, the field for this experiment was plowed, prepared, and fumigated with methylisothiocyanate (Vorlex; Nor-Am Chemical Co., Wilmington, Del.) (258 kg a.i./ ha). Soil samples were taken in Mar. 1991 and required nutrient applications were incorporated by rototilling. Before planting, the trees were dipped in a $2.5 \%$ solution of petroleum oil (Sunspray 6E; Sun Oil and Refining Co., 


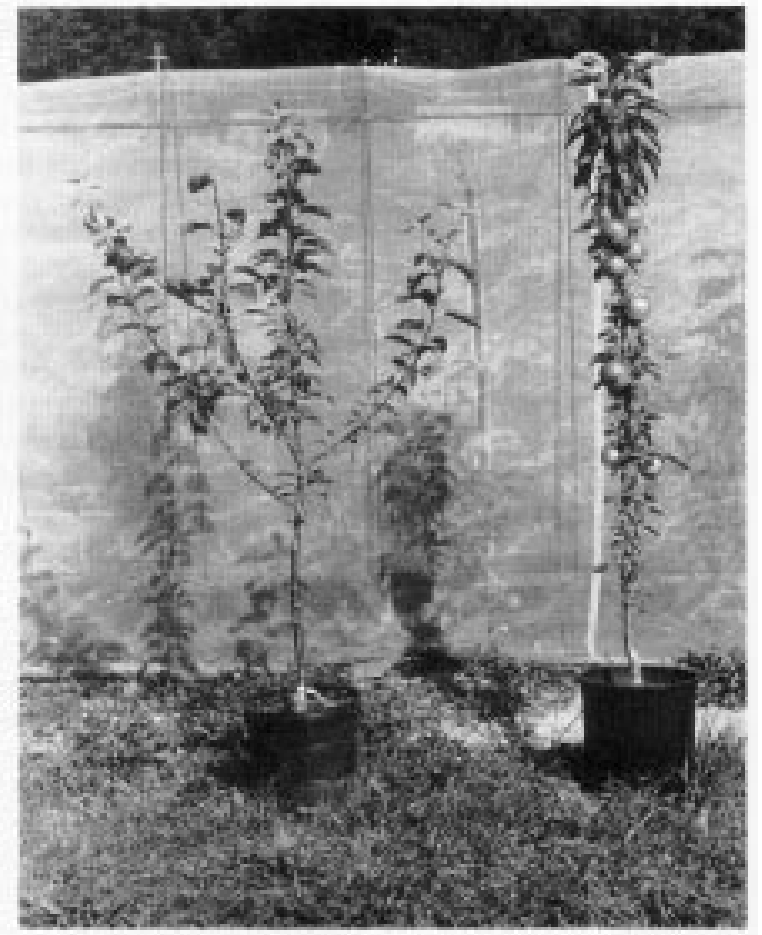

Fig. 1. (left) Standard-form apple tree compared to (right) columnar-form apple tree.

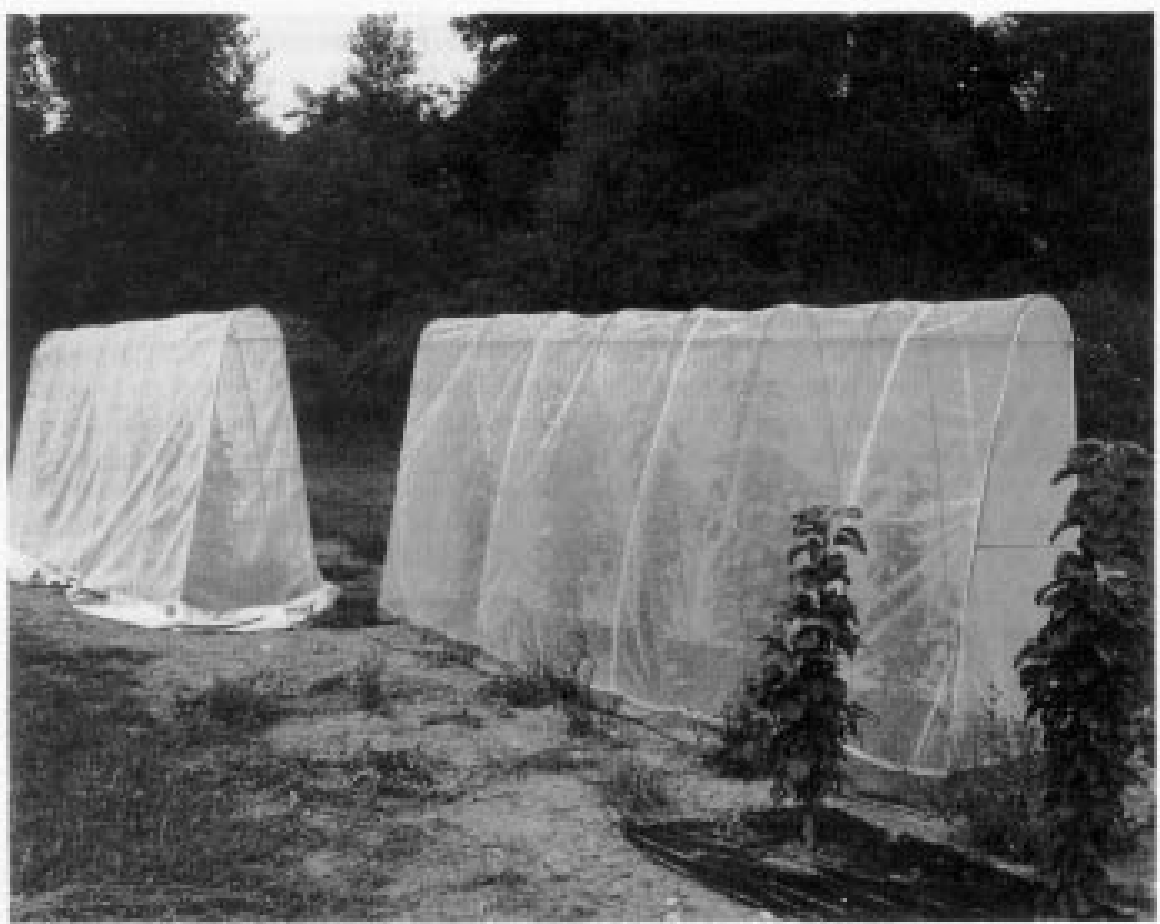

Fig. 2. Large insect-exclusionary cages placed over five columnar apple trees.

Marcus Hook, Pa.) to control overwintering pests such as mites, aphids, and leafhoppers. On 19 Apr., soil around the newly planted trees was treated with 0.95 liters of dilute metalaxyl (Ridomil 2E; Ciba-Geigy Corp., Greensboro, N.C.) (0.63 ml a.i./tree) to control diseases caused by Phytophthora and Pythium spp.

Additional chemicals were applied to trees in the large cages with a hand-operated backpack sprayer delivering $\approx 0.11$ liters of dilute material per tree. Chemicals used were either nondisruptive to beneficial arthropods or were selective for certain arthropod pests. On 14 May, 21 May, and 4 June 1991 and 6 May, 14 May, and 28 May 1992, all trees received applications of myclobutanil [Nova (40\% W), Rohm and Haas Co., Philadelphia] (0.007 g a.i./tree) for control of apple scab [Venturia inaequalis (Cooke)], powdery mildew [Podosphaera leucotricha (Ell. \& Ev.)], and cedar apple rust (Gymnosporangium juniperivirginianae Schwein). Treatment six received season-long insecticide applications. These included Bacillus thuringiensis (Javalin WG; Sandoz Crop Protection Corp., Des Plaines, Ill.) (0.012 g a.i./tree) 20 May 1991 and 4 June 1992 for control of obliquebanded leafrollers [Choristoneura rosaceana (Harris)]; chlorpyrifos [Losban $(50 \% \mathrm{~W})$; Dow Chemical Co., Midland, Mich] (0.08 g a.i./tree) on 4 June and 31 July 1991 and 1 July 1992 for control of obliquebanded leafrollers, and an aphid complex composed of apple aphids (Aphis pomi De Geer) and spirea aphids ( $A$. spiraecola Patch); oxamyl (Vydate L; E.I. du Pont de Nemours \& Co., Wilmington, Del.) (0.026 ml a.i./tree) on 1 July 1991 and 14 May 1992 for control of spotted tentiform leafminers (Phyllonorycter blancardella Fabricius); and endosulfan [thiodan (50\% W); FMC Corp., Philadelphia] (0.07 g a.i./tree) 6 Aug. 1992 for control of apple and spirea aphids. During 1991, herbicide was used to control weeds in and around the cages. On 20 May, oryzalin (Surflan; Elanco Products Co., Indianapolis), 0.34 liters a.i./ha was sprayed around the cages, and on 4 June a $25 \%$ solution of glyphosate (Roundup; Monsanto Agricultural Co., Saint Louis) was applied with a hand-held roller directly to weeds inside the cages.

In 1992, the large-mesh material was replaced because it was not ultraviolet stable. The replacement material ("PC-33," white polyester, pore size $3.0 \times 3.0 \mathrm{~mm}$; Apex Mills Corp.) had the same pore size but slightly larger thread diameter than the original material. In that same year, landscaping fabric (Belton Industries, Belton, S.C.) was used to prevent weed growth inside the cages. Fertilizer requirements were assessed from 1991 leaf samples, and fertilizer was applied by broadcasting to all blocks.

Small cages and mesh coverings were made from the same materials described for the large cages. The small cages were rectangular and measured $40.5 \mathrm{~cm} \times 40.5 \mathrm{~cm} \times 2.1 \mathrm{~m}$ high (Fig. 3 ). Each cage housed one potted apple tree. Seven treatments were examined: three consisted of fine-, medium-, and large-mesh material that fully enclosed the trees; three consisted of fine, medium, and large mesh with open tops; and the control treatment was not caged or sprayed with insecticides. The treatments were randomized in each of six blocks, in a randomized complete-block design. Each block contained one replicate of each treatment. The caged trees were placed in the drive rows of a source orchard that harbored a large population of arthropod pests.

'Starkspur Compact Mac'/MM.106 apple trees were potted on 15 May 1990 in 19-liter plastic pots containing a mixture of $50 \%$ silty loam and 50\% Cornell artificial mix. These uncaged, potted trees were placed outside during the 1990 growing season and were then overwintered in a cool greenhouse. On 10 Mar. 1991, the potted trees bloomed in the greenhouse and were hand-pollinated. Each tree was fertilized on 10 Mar. 1991 with $75 \mathrm{~g}$ of 14-14-14 Osmocote fertilizer (Grace-Sierra Horticultural Product Co., Milpitas, Calif.). The potted trees, cages, and mesh coverings were placed in the source orchard when it was at the full-bloom stage on 10 May 1991. 


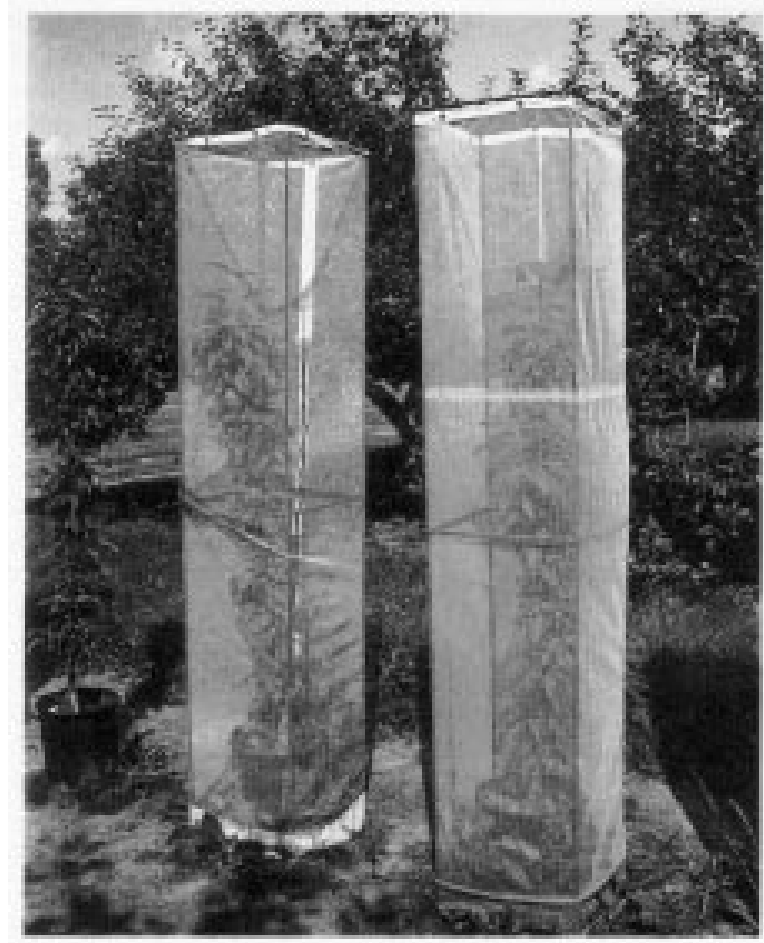

Fig. 3. Small insect-exclusionary cages placed over potted columnar apple trees.

In 1992, the trees were removed from cold storage on 10 Apr. Nutrients were applied according to recommendations from leaf analyses in 1991. On 24 Apr. 1992, when all trees in the experiment were at the green-tip stage, the potted trees and mesh coverings were placed in the source orchard in the same locations they had occupied during the 1991 season. On 18 May, the potted and source orchard trees were at full bloom, and the potted trees were hand-pollinated. As in the other study, the large-mesh coverings were replaced in 1992 with an ultraviolet stable material (PC-33).

Potted trees were sprayed with myclobutanil [Nova $(40 \% \mathrm{~W})](0.007 \mathrm{~g}$ a.i./tree) on $10 \mathrm{May}$, 21 May, 4 June, and 13 June 1991 and 6 May, 14 May, and 28 May 1992 for control of apple scab, powdery mildew, and cedar apple rust; captan [Captan (50\% W); ICI Americas, Wilmington, Del.] (0.41 g a.i./tree) 13 June 1991 for control of apple scab; and propargite (Omite 6E; Uniroyal Chemical Co., Middlebury, Conn.) (0.06 ml a.i./tree) 4 and 13 May 1991 for control of European red mite [Panonychus ulmi (Kock)], apple rust mite [Aculus schlectendali (Nalepa)], and two-spotted spider mite (Tetranychus urticae Koch).

Each potted tree received $\approx 8$ liters of water every other day. The trees and mesh coverings were removed from the field after leaf fall during 1991 and 1992. The metal frames were left in the field to ensure that potted trees would be placed in the same location in 1992.

Environmental characteristics were measured in the large-cage study throughout the 1991 and 1992 growing seasons. Tensiometers were installed between the middle trees in all plots, and readings were taken twice weekly until 17 June 1991, when the soil was too dry to obtain accurate readings, and until the end of Aug. 1992. Rain gauges were placed between the middle tree and the tree immediately to the north in all plots. Rain volumes were recorded and the gauges were emptied after every measurable rain. Light intensity, evaporation, relative humidity, and soil and air temperature were measured four times during 1991 and twice during 1992. Evaporation was measured by filling white plastic containers $(16 \times 16 \times 10 \mathrm{~cm})$ with $1000 \mathrm{ml}$ of water and placing them in all treatments in one block at $0830 \mathrm{HR}$ and then measuring the volume of water remaining at $1630 \mathrm{HR}$. The other environmental measurements were recorded at 0900, 1200, and 1500 HR. Light intensity was recorded with a LI-COR quantum/radiometer/photometer (model Li-185A; LI-COR, Lincoln, Neb.) with the sensor positioned $1 \mathrm{~m}$ aboveground in the middle of each treatment. Air temperature and relative humidity were measured using a Cole-Parmer LCD digital hygrometer (model 3309-50; ColeParmer, Chicago) held $1 \mathrm{~m}$ aboveground in the middle of each treatment. Soil temperature was recorded from a thermometer inserted to a depth of $4.5 \mathrm{~cm}$ in the middle of each plot. Continuous light measurements were recorded from 12 Aug. through 16 Aug. 1991 in one replicate of each treatment with a $21 \mathrm{X}$ micrologger (Campbell Scientific, Logan, Utah). Average hourly reading from 0400 until 2200 HR was recorded.

In the small-cage study, light intensity was examined using two methods. Light readings were taken at 1000,1200, and $1400 \mathrm{HR}$ in all treatments from two blocks, using the LI-COR instrument positioned in the center of the cage $0.5 \mathrm{~m}$ below the top on 6 June, 17 July, and 15 Aug. 1991 and 3 June and 20 July 1992. Continuous light readings were recorded in the center of the cage $0.5 \mathrm{~m}$ below the top from 16 to 20 Aug. 1991 in all treatments in one block using the same technique described for the large cages.

Tree characteristics were recorded for the large-cage study throughout the season. On 13 May 1991, all trees were marked with white paint $10 \mathrm{~cm}$ above the graft union. Trunk diameter was measured at this mark. Transpiration rates were measured 19 June, 16 July, 30 July, and 15 Aug. 1991 and 3 June and 20 July 1992 on small potted 'Starkspur Compact Mac'/MM.106 trees that had been placed inside the large-cage treatments. These trees were in 3.8-liter plastic pots wrapped in aluminum foil and watered the night before being placed in the field. Trees were weighed at $0800 \mathrm{HR}$, and each mesh treatment in a block had one potted tree placed inside the cage. One of the two uncovered groups of trees was used as a control. At 1630 HR on that same day the potted trees were removed from the treatments and weighed. A LI-COR portable area meter (model LI-3000) was used to measure 10 leaves chosen randomly from each of the 10 potted trees. The average from the 100-leaf sample was multiplied by the total number of leaves per tree to obtain the total leaf area of each potted tree. The amount of water lost during the day was expressed as weight loss per square centimeter of leaf area.

On 25 June 1992, gas exchange [net photosynthesis (Pn), transpiration (E), and leaf conductance $\left(\mathrm{g}_{\mathrm{l}}\right)$ ] was measured on two mature bourse-shoot leaves from two in-ground trees per treatment in the large-cage study. The measurements were made with an LCA-2 portable gas-exchange system (ADC, Hoddesdon, Herts, UK). The system used an open, flowthrough, clamp-on leaf chamber with $6.25 \mathrm{~cm}^{2}$ of leaf area enclosed. Carbon dioxide differentials averaged 20 to $30 \mathrm{ppm}$. Transpiration (E) was estimated by the difference between the equilibrium relative humidity and temperature with the leaf enclosed and the relative humidity and temperature after the leaf was removed from the chamber. Measurements were made in the middle of the day under sunny conditions with leaves at 24 to $26 \mathrm{C}$.

Tree growth was assessed by measuring trunk diameter and current-season shoot elongation on 28 Oct. 1991 and 29 Sept. 1992. Internode length of current-season growth was measured on the latter date. Cumulative tree growth from both years was also estimated.

Fruit from the small-cage experiment was rated for color development on the exposed side of the fruit at weekly intervals from 25 June through 26 Aug. 1991 and 6 Aug. through 1 Sept. 1992. A scale of 1 to 4 was used with $1=$ green and $4=$ red. During 1991, fruit were allowed to abscise naturally, and length, width, weight, firmness (average force required to push a $1.2-\mathrm{cm}$ plunger $8.0 \mathrm{~mm}$ into the pared flesh of the fruit), level of maturity (starchiodine test), soluble solids concentration (average of two refractometer readings per fruit), and color $(<25 \%,>25 \%<33 \%,>33 \%<50 \%$, $>50 \%<80 \%$, and $>80 \%$ of surface red) were measured. In 1992, all fruit were harvested on 8 Sept., and the same measurements as in 1991 were made.

Arthropod populations were estimated 
throughout the study in insect-exclusionary cages, and a complete account of all arthropods examined is given by Lawson et al. (1993). Only phytophagous insect data recorded from the large insect-exclusionary cages will be presented. Leaf damage caused by the spotted tentiform leafminer was evaluated on 29 July and 13 Aug. 1991 and 6 Aug. 1992 by counting the total number of mines per leaf on the five leaves immediately above the most recent year's growth ring on all five trees per treatment. Leaf damage caused by the apple leaf skeletonizer Choreutis pariana (Clerk) was evaluated on 10 July 1991 and 6 Aug. 1992 by counting the total number of leaves damaged on all five trees per treatment. On 12 June 1991, the number of mines caused by Lyonetia speculella Clemens on the 10 most terminal leaves from each of the five trees per treatment was counted. Potato leafhopper Empoasca fabae (Harris) nymphs were counted on the three most terminal leaves from each of five trees per treatment on 17 and 28 June and 27 Aug. 1991 and on the four most terminal leaves 6 Aug. 1992.

The effects of insect-exclusionary cages on tree performance during each year of this study were examined separately. Separate analyses were made for two reasons. First, the different-aged trees (newly planted vs. 1 year old) used in this study were morphologically different (e.g., root zone and canopy size), which was expected to influence plant performance. Second, weather patterns were substantially different between years; 1991 was sunny, hot, and dry, while 1992 was cloudy, cool, and wet. The effect these distinct environmental conditions had on photosynthesis, water status, and overall plant performance could be influenced by the morphological differences between newly planted and 1-yearold trees (Jackson, 1980; Jones et al., 1985; Schulze et al., 1974).

Statistical analyses. Nonpercent data were normalized with a $\log _{10}(x+1)$ transformation, and percent data were transformed using the arcsin square-root transformation. Data collected on more than one date were subjected to a repeated measures analysis of variance (ANOVA). If a significant treatment $\times$ time interaction existed, data were analyzed at each individual date or, if appropriate, as seasonal averages (Abacus Concepts, 1989). Averages of the three daily measurements of light, air and soil temperature, and relative humidity were analyzed. Data were subjected to ANOVA, and means were compared using Fisher's protected least significant difference (LSD) test (Abacus Concepts, 1989). On-tree fruit color ratings were analyzed using a weighted ANOVA (SAS Institute, 1985). Fruit color at harvest was evaluated using a proportional-odds model, and means were compared using a $t$ test approximation (McCullagh, 1980). For all analyses, the comparisonwise error rate was $<0.05$. The regression between tree growth and light intensity was generated using SYSTAT(Wilkinson, 1989). Continuous light intensity data and fruit quality data from 1991 could not be analyzed because they lacked replication.

\section{Results}

Environmental characteristics. Soil water potential, as measured by tensiometers, showed no significant differences among treatments in either 1991 or 1992 (Table 1). Rain penetration was significantly reduced within all cages in 1991 and 1992. In both years, the uncovered control plots received more rain than any of the covered treatments, and in 1992 the medium-O plots received more rain than any other caged plots.

Air temperature inside the large insectexclusionary cages was similar for all treatments during 1991. However, in 1992, air temperatures in the fine- and medium-meshcovered cages were higher than for the uncovered control (Table 1).

Soil temperature varied significantly among treatments in both years. During 1991, the uncovered control had the highest temperature and the medium and medium-O cages had the lowest temperature. During 1992, the uncovered control also had the highest soil temperature and only subtle differences occurred among the caged treatments (Table 1).

Evaporation rates were similar among all covered treatments, but significantly lower than those for the uncovered control during both years (Table 1).

Light measurements recorded continuously in the large cages revealed results similar to those recorded three times during the day. However, continuous readings showed that the greatest differences in light intensity occurred between 1000 and $1400 \mathrm{HR}$. In both years, light intensity varied significantly among the treatments, being highest in the uncovered control and lowest under medium mesh in 1991; in 1992, there was no difference among the covered cages, all of which received less light than the uncovered control (Table 1). Light measurements in small cages showed similar results between the two methods of measurement. Continuous measurements revealed the largest differences among treat-

Table 1. Environmental measurements recorded in large insect-exclusionary cages.

\begin{tabular}{lccccc}
\hline & \multicolumn{5}{c}{ Cage pore size } \\
\cline { 2 - 4 } Environmental characteristics & Fine & Medium & Medium-O & Large & Control \\
\cline { 2 - 5 } & & 1991 & & \\
Soil water potential $(\mathrm{kPa})^{\mathrm{z}}$ & $27.7 \mathrm{a}^{\mathrm{y}}$ & $24.9 \mathrm{a}$ & $20.7 \mathrm{a}$ & $28.9 \mathrm{a}$ & $19.5 \mathrm{a}$ \\
Total seasonal rain $(\mathrm{mm})$ & $90 \mathrm{a}$ & $89 \mathrm{a}$ & $97 \mathrm{a}$ & $92 \mathrm{a}$ & $121 \mathrm{~b}$ \\
Air temperature $\left({ }^{\circ} \mathrm{C}\right)$ & $30.6 \mathrm{a}$ & $29.9 \mathrm{a}$ & $30.2 \mathrm{a}$ & $29.8 \mathrm{a}$ & $29.3 \mathrm{a}$ \\
Soil temperature $\left({ }^{\circ} \mathrm{C}\right)$ & $27.6 \mathrm{~b}$ & $26.3 \mathrm{a}$ & $26.5 \mathrm{a}$ & $27.6 \mathrm{~b}$ & $29.6 \mathrm{c}$ \\
Relative humidity $(\%)$ & $39.4 \mathrm{a}$ & $40.8 \mathrm{a}$ & $41.4 \mathrm{a}$ & $40.5 \mathrm{a}$ & $42.3 \mathrm{a}$ \\
Evaporation $(\%$ of control) & $71.1 \mathrm{a}$ & $68.5 \mathrm{a}$ & $74.2 \mathrm{a}$ & $77.5 \mathrm{a}$ & $100 \mathrm{~b}$ \\
Light $(\%$ of control) & $79.4 \mathrm{~b}$ & $65.8 \mathrm{a}$ & $81.3 \mathrm{~b}$ & $84.4 \mathrm{~b}$ & $100 \mathrm{c}$ \\
& & & & $12.5 \mathrm{a}$ & $11.6 \mathrm{a}$ \\
Soil water potential $(\mathrm{kPa})$ & $12.4 \mathrm{a}$ & $10.8 \mathrm{a}$ & $10.3 \mathrm{a}$ & $246 \mathrm{a}$ & $348 \mathrm{c}$ \\
Total seasonal rain $(\mathrm{mm})$ & $239 \mathrm{a}$ & $240 \mathrm{a}$ & $264 \mathrm{~b}$ & $27.9 \mathrm{ab}$ & $26.9 \mathrm{a}$ \\
Air temperature $\left({ }^{\circ} \mathrm{C}\right)$ & $29.2 \mathrm{c}$ & $28.3 \mathrm{bc}$ & $27.8 \mathrm{ab}$ & $19.8 \mathrm{ab}$ & $22.3 \mathrm{c}$ \\
Soil temperature $\left({ }^{\circ} \mathrm{C}\right)$ & $20.1 \mathrm{~b}$ & $19.1 \mathrm{a}$ & $20.0 \mathrm{~b}$ & $65.6 \mathrm{a}$ & $100 \mathrm{~b}$ \\
Evaporation $(\%$ of control) & $67.0 \mathrm{a}$ & $66.7 \mathrm{a}$ & $75.7 \mathrm{a}$ & $71.6 \mathrm{a}$ & $100 \mathrm{~b}$ \\
Light $(\%$ of control) & $73.8 \mathrm{a}$ & $67.1 \mathrm{a}$ & $80.0 \mathrm{a}$ & & \\
\hline
\end{tabular}

${ }^{\mathrm{z}}$ Measurements taken from 15 May through 17 June.

${ }^{y}$ Mean separation in rows by LSD at $P \leq 0.05$ (rain 1991: $\mathrm{F}=43.81$; treatment $\mathrm{df}=4$, error df $=22 ; 1992: \mathrm{F}$ $=92.15$; treatment $\mathrm{df}=4$, error $\mathrm{df}=22$; air temperature 1992: $\mathrm{F}=8.79$; treatment $\mathrm{df}=4$, error $\mathrm{df}=4$; soil temperature 1991: $\mathrm{F}=46.75$; treatment $\mathrm{df}=4$, error $\mathrm{df}=8 ; 1992: \mathrm{F}=38.21$; treatment $\mathrm{df}=4$, error $\mathrm{df}=4$; evaporation 1991: $\mathrm{F}=23.42 ;$ treatment $\mathrm{df}=4$, error $\mathrm{df}=8 ; 1992: \mathrm{F}=21.98$; treatment $\mathrm{df}=4$, error $\mathrm{df}=4$; light 1991: $\mathrm{F}=17.18$; treatment $\mathrm{df}=4$, error $\mathrm{df}=24 ; 1992: \mathrm{F}=30.96$; treatment $\mathrm{df}=4$, error $\mathrm{df}=4$ ). Nontransformed data presented. Significant differences in light intensity were observed during both years (Fig. 4). In 1991 (top cages had higher Among the fully enclosed treatments, the medium mesh had the lowest and the largemesh cages had the highest light intensity. uring 1992, the control had the highest light level followed by all open-top and then the fully enclosed treatments.

Plant attributes. Whole-tree transpiration rates were similar for all treatments in both years, as were gas-exchange measurements (Pn) in $1992\left[17.9-19.9\left(\mu \mathrm{mol}\left(\mathrm{CO}_{2}\right) / \mathrm{m}^{2} / \mathrm{s}\right)\right]$.

Significant differences were recorded for foliar N concentrations during 1991, which were higher in trees from the insecticide treatment compared to the uncovered-unsprayed control and large-mesh plots. During 1992, N concentrations were lower in trees grown in the uncovered-unsprayed control plots than in the insecticide-treated control, fine-, medium-, and medium-O-mesh-covered cages. Other foliar nutrient concentrations were variable among trees grown in the various plots, with o clear trends evident (Table 2).

Shoot elongation during 1991 was similar among trees in the various treatments; howlonger shoots than trees in either of the uncovered plots. The relationship between shoot elongation and percent full sunlight is expressed in the regression line that indicates that shoot growth was negatively related to light intensity (Fig. 5), which accounted for $55.0 \%$ of the total variation in shoot growth uring 1992

Trunk diameter was unaffected by the treatments in 1991 and 1992 (Table 2). However, when total shoot and trunk growth measurements for the two years were combined, significant differences among trees in the treatments were evident (Table 2). Total shoot light intensities than the fully enclosed cages. and fine-O had the highest light intensity. 


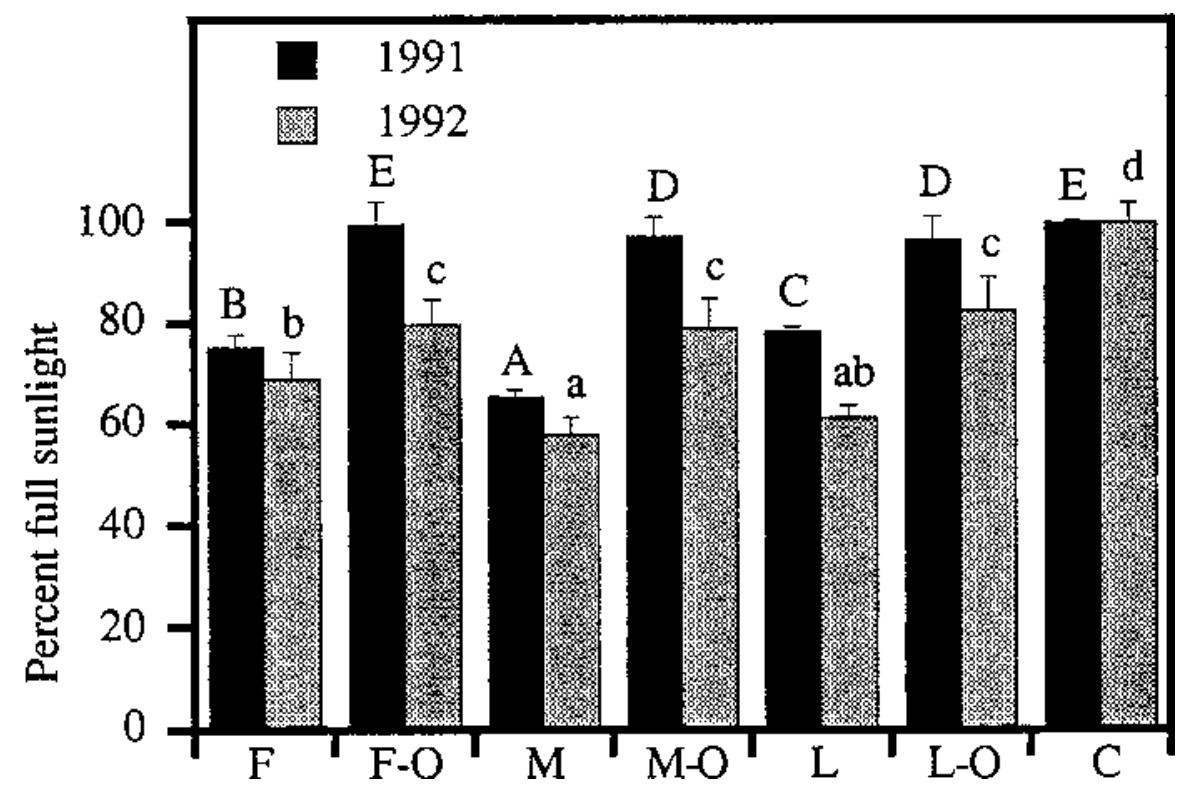

Fig. 4. Percentage of full sunlight recorded in fully enclosed, small, insect-exclusionary cages with fine (F), medium (M), and large (L) pore size; in cages with the tops open (F-O, M-O, and L-O); and in an uncovered control (C). Mean separation for each year by LSD at $P \leq 0.05$ (for all analyses: treatment $\mathrm{df}$ $=6$, error df $=6 ; 1991: \mathrm{F}=8.34 ; 1992: \mathrm{F}=43.55)$.

Table 2. Measurements recorded for columnar apple trees grown in large insect-exclusionary cages.

\begin{tabular}{|c|c|c|c|c|c|c|}
\hline \multirow[b]{2}{*}{ Plant characteristics } & \multicolumn{4}{|c|}{ Cage pore size } & \multicolumn{2}{|c|}{ Controls } \\
\hline & Fine & Medium & Medium-O & Large & Unsprayed & Insecticide \\
\hline \multicolumn{7}{|c|}{1991} \\
\hline \multicolumn{7}{|l|}{$\begin{array}{l}\text { Transpiration } \\
\text { (\% of control) }\end{array}$} \\
\hline $\mathrm{N}$ (\% dry weight) & $2.1 \mathrm{a}-\mathrm{c}$ & $2.2 \mathrm{bc}$ & $2.1 \mathrm{a}-\mathrm{c}$ & $2.0 \mathrm{a}$ & $2.0 \mathrm{ab}$ & $2.3 \mathrm{c}$ \\
\hline $\mathrm{Ca}$ (\% dry weight) & $0.9 \mathrm{a}-\mathrm{c}$ & $1.0 \mathrm{bc}$ & $1.0 \mathrm{c}$ & $0.9 \mathrm{ab}$ & $0.8 \mathrm{a}$ & $0.9 \mathrm{a}-\mathrm{c}$ \\
\hline $\mathrm{B}(\mathrm{ppm})$ & $30.7 \mathrm{bc}$ & $27.5 \mathrm{a}$ & $29.2 \mathrm{ab}$ & $30.1 \mathrm{bc}$ & $31.7 \mathrm{c}$ & $29.7 \mathrm{bc}$ \\
\hline Shoot elongation $(\mathrm{cm})$ & $22.7 \mathrm{a}$ & $19.1 \mathrm{a}$ & $20.6 \mathrm{a}$ & $19.1 \mathrm{a}$ & $14.8 \mathrm{a}$ & $20.7 \mathrm{a}$ \\
\hline Trunk diameter (mm) & $5.2 \mathrm{a}$ & $4.7 \mathrm{a}$ & $5.0 \mathrm{a}$ & $4.6 \mathrm{a}$ & $3.9 \mathrm{a}$ & $4.6 \mathrm{a}$ \\
\hline \multicolumn{7}{|c|}{1992} \\
\hline $\begin{array}{l}\text { Transpiration } \\
\text { (\% of control) }\end{array}$ & $100 \mathrm{a}$ & $91 \mathrm{a}$ & $102 \mathrm{a}$ & $87 \mathrm{a}$ & $100 \mathrm{a}$ & --- \\
\hline $\mathrm{N}$ (\% dry weight) & $2.4 \mathrm{c}$ & $2.4 \mathrm{c}$ & $2.4 \mathrm{bc}$ & $2.2 \mathrm{ab}$ & $2.1 \mathrm{a}$ & $2.4 \mathrm{bc}$ \\
\hline $\mathrm{B}(\mathrm{ppm})$ & $31.1 \mathrm{ab}$ & $30.4 \mathrm{a}$ & $33.2 \mathrm{a}-\mathrm{c}$ & $36.6 \mathrm{c}$ & $35.2 \mathrm{bc}$ & $34.7 \mathrm{bc}$ \\
\hline Shoot elongation $(\mathrm{cm})$ & $42.7 \mathrm{~b}$ & $42.1 \mathrm{~b}$ & $41.4 \mathrm{~b}$ & $40.8 \mathrm{~b}$ & $31.3 \mathrm{a}$ & $33.4 \mathrm{a}$ \\
\hline Trunk diameter (mm) & $23.4 \mathrm{a}$ & $21.3 \mathrm{a}$ & $20.9 \mathrm{a}$ & $20.3 \mathrm{a}$ & $20.8 \mathrm{a}$ & $21.2 \mathrm{a}$ \\
\hline Internode length $(\mathrm{cm})$ & $1.4 \mathrm{a}$ & $1.5 \mathrm{a}$ & $1.4 \mathrm{a}$ & $1.5 \mathrm{a}$ & $1.3 \mathrm{a}$ & $1.6 \mathrm{a}$ \\
\hline Branch number & $4.6 \mathrm{a}$ & $3.6 \mathrm{a}$ & $3.8 \mathrm{a}$ & $3.1 \mathrm{a}$ & $3.8 \mathrm{a}$ & $3.9 \mathrm{a}$ \\
\hline \multicolumn{7}{|l|}{ Total growth 1991-92 } \\
\hline Shoot elongation $(\mathrm{cm})$ & $65.4 \mathrm{c}$ & $61.2 \mathrm{c}$ & $62.0 \mathrm{c}$ & $59.9 \mathrm{bc}$ & $46.0 \mathrm{a}$ & $54.1 \mathrm{~b}$ \\
\hline Trunk diameter (mm) & $28.6 \mathrm{~b}$ & $25.9 \mathrm{a}$ & $25.8 \mathrm{a}$ & $24.9 \mathrm{a}$ & $24.7 \mathrm{a}$ & $25.7 \mathrm{a}$ \\
\hline
\end{tabular}

${ }^{2}$ Mean separation in rows by LSD at $P \leq 0.05$ (for all analyses: treatment $\mathrm{df}=5$, error $\mathrm{df}=27 ; \mathrm{N} \mathrm{1991: \textrm {F } =}$ 2.67; 1992: $\mathrm{F}=3.97 ; \mathrm{B} 1991: \mathrm{F}=3.62 ; 1992: \mathrm{F}=2.73 ; \mathrm{Ca} 1991: \mathrm{F}=2.67 ;$ shoot elongation $1992: \mathrm{F}=9.31 ;$ total shoot elongation: $\mathrm{F}=8.26$; total trunk diameter: $\mathrm{F}=3.13$ ). Nontransformed data presented.

elongation was greatest for all trees grown inside insect-exclusionary cages compared to trees grown as the uncovered-unsprayed control treatment. Total trunk diameter was largest for trees grown in the fine-mesh treatment. No significant differences were recorded for internode length or branch count, which were measured only in 1992 (Table 2).

On-tree fruit color ratings revealed that the greatest color variation occurred among apples grown in the various treatments early in the season and decreased as the season progressed (Fig. 6). At the end of the season, fruit color, rated while the apples were still on the tree, was the same among all treatments during both years (Fig. 6). However, differences in color were significant for apples harvested from the various treatments in 1992. Fruit from trees in uncovered plots had the largest proportion of fruit in the $>80 \%$ red category (Table 3 ). The lowest proportion of fruit in the $>80 \%$ red category came from trees grown in mediumand medium-O-mesh cages. The only significant difference detected in fruit quality measurements from 1992 was fruit firmness. The firmest fruit were harvested from the unsprayed and fine-O-mesh treatments (data not shown).

Phytophagous insect counts. Foliar damage caused by the spotted tentiform leafminer differed significantly among treatments in both years (Table 4). In 1991, the fewest mines per leaf (zero) were recorded on insecticide-treated trees, while the most mines were observed on uncovered-unsprayed trees and trees grown inside large-mesh-covered cages. In 1992, trees in the fine-mesh cages had more mines per leaf than those in any of the other cages. Another leafminer, L. speculella, caused a pattern of foliar damage similar to that of the spotted tentiform leafminer during 1991; greatest leaf damage occurred on trees in the uncagedunsprayed control, followed by the large and medium-O cages, and the least damage (zero) was recorded from trees in the fine, medium, and insecticide treatments (Table 4).

Foliar damage caused by the apple leaf skeletonizer differed significantly among treatments both years. The uncovered-unsprayed control trees consistently had the highest level of damage (Table 4). In 1991, foliar damage in all other treatments was similar, but less than the uncaged-unsprayed control. In 1992, trees in the fine and medium mesh had the least foliar damage (zero), followed by trees in the large-mesh cages and those uncaged and sprayed with insecticides.

Potato leafhopper densities varied in the large-cage study during 1991 (Table 4). Trees in the medium-, medium-O-, and fine-mesh treatments had the lowest densities, while higher densities were found on trees in the large-mesh, uncovered-unsprayed, and uncovered and insecticide-sprayed control treatments. In 1992, all mesh-covered trees had zero infestation, which was significantly lower than that obtained with either the unsprayed or insecticide-sprayed trees.

\section{Discussion}

Although subtle differences occurred among treatments for many of the environmental variables measured, many were not significant. Light intensity was the characteristic most affected by insect-exclusionary cages. Lakso and Seeley (1978) stated that solar radiation is the predominant factor influencing the microclimate of fruit crops, because it affects photosynthesis, flowering, fruit set, and fruit quality (Barden, 1977; Jackson, 1980; Robinson et al., 1983). The lowest light intensities recorded in our study were in the medium-mesh cages, where light was reduced $34 \%$ (Table 1). Heinicke (1965) stated that maximum photosynthetic rates in apple may be reached at one-half to one-third full sunlight, and Rom (1991) reported maximum photosynthesis at $45 \%$ to $55 \%$ full sunlight. Photosynthetic measurements taken during 1992 showed no reductions inside the various exclusionary cages when compared to uncaged trees, indicating that the light saturation point for apple had been achieved inside the cages. Plant form does affect photosynthetic efficiency, and small trees are more efficient users of light than large trees because of better light penetration through the outside canopy (Jackson, 1980; Mika and Antoszewski, 1972). Jones et al. (1991) stated that all leaves on columnar-form trees have good light exposure because there is no shading from outside canopy leaves. Therefore, even with a $34 \%$ reduction of ambient sunlight, these columnar-form trees were still receiving sufficient light to maintain maximum photosynthesis. 


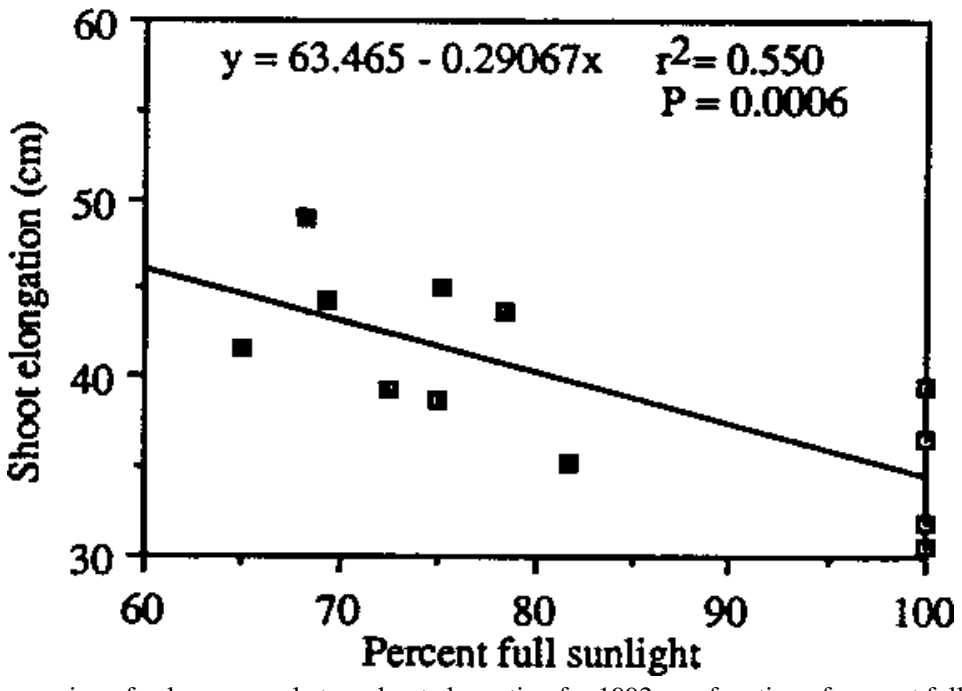

Fig. 5. Regression of columnar apple tree shoot elongation for 1992 as a function of percent full sunlight.
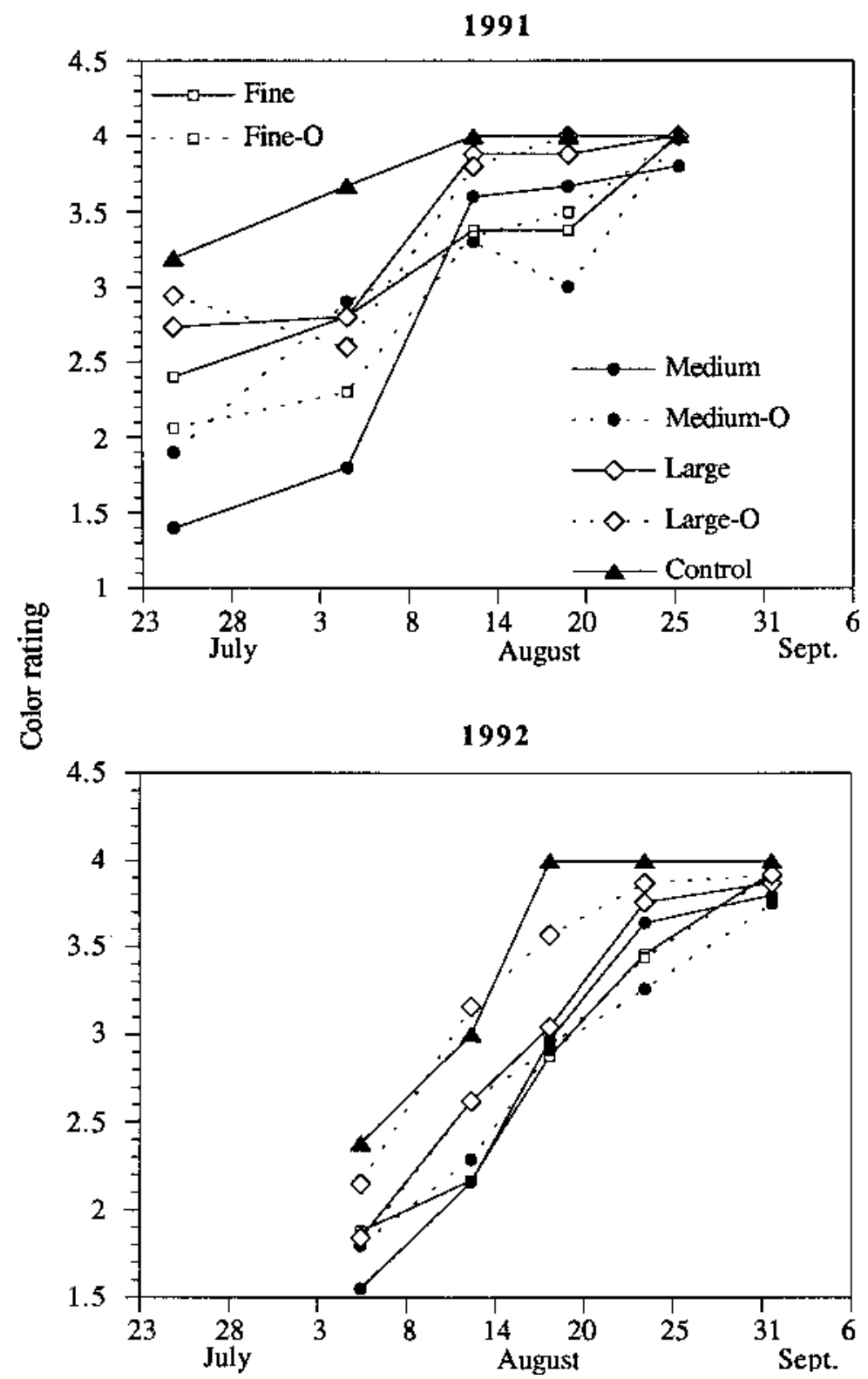

Fig. 6. On-tree fruit color ratings from columnar apples in small insect-exclusionary cages. Color scale: 1 $=$ green and $4=\operatorname{red}$ (for all analyses: treatment $\mathrm{df}=24 ; 1991: \mathrm{F}=1.64 ; 1992: \mathrm{F}=2.21, P \leq 0.05$, weighted analysis of variance)
Although evaporative rates and light intensity were highest in the uncovered control during both years, transpiration was similar for potted whole trees, likely because these well-watered trees were capable of effective osmoregulation under conditions of high evaporative demands (Jones, 1983; Schulze et al., 1974).

Rain accumulation varied among the treatments, but soil water potential was similar in all treatments. Either water running off the cages moved through the soil and into the cages, or decreased evaporation rates inside the insect-exclusionary cages compensated for decreased rain accumulation inside the cages.

Tree growth was not adversely affected by insect-exclusionary cages during either year. During 1992, tree performance, as measured by shoot growth, was better inside insectexclusionary cages compared to either uncovered control. Priestly (1969) reported reduced shoot and root growth from apple trees grown under $77 \%$ to $90 \%$ shade, and Barden (1977) reported decreased stem diameter in trees grown under $80 \%$ shade. However, Priestly (1969) reported that trees grown under $90 \%$ shade grew more than expected. He later showed that the new shoot growth was less woody than that of trees grown in full sunlight. These findings may be the result of etiolation, which is easily measured by internode length, and in our study was similar for all treatments.

Foliar damage caused by phytophagous insects was similar for the insecticide-sprayed trees and those covered with fine- and medium-mesh cages. Lawson et al. (1994) showed that direct fruit damage caused by insects was most severe in the uncovered-unsprayed control and in the large-mesh cages. Therefore, control of direct and indirect fruit-damaging arthropod pests without the use of insecticides can be achieved using insect-exclusionary cages covered with fine and medium mesh.

Although the uncaged-unsprayed control trees in the large-cage study sustained severe leaf damage, no significant effect of herbivory on tree growth was apparent in either year. However, the cumulative effects of severe foliage damage by arthropods were evident in the uncaged-unsprayed control when tree growth was factored over both years of the study. The uncaged-unsprayed control trees had the least shoot elongation, but trunk diameter was unaffected. Ferree et al. (1986) reported that simulated insect damage, which removed $7.5 \%$ of the leaf area, had no influence on photosynthesis. However, when $10 \%$ of the leaf was removed, photosynthetic levels began to decrease. Other authors have reported similar decreases in photosynthesis from plants damaged by arthropods (Ames et al., 1984; Hall and Ferree, 1975). However, in our study, photosynthetic rates measured in the uncovered-unsprayed control trees were as high as those in the sprayed control. This unaltered photosynthetic rate may be the result of the plant compensating for leaf injury caused by arthropod feeding (Layne and Flore, 1992; Syvertsen et al., 1986).

Nutritional status of all trees in the largecage study was within recommended levels, 
Table 3. Columnar apple color ratings at harvest from small insect-exclusionary cages (1992).

\begin{tabular}{lcrcccr}
\hline \hline Cage pore & & \multicolumn{4}{c}{$\%$ Fruit in each color category } \\
\cline { 3 - 7 } size & $n$ & $\langle 25 \%$ & $>25 \%<33 \%$ & $>33 \%<50 \%$ & $>50 \%<80 \%$ & $>80 \%$ \\
\hline Fine & 62 & 0.0 & 24.8 & 43.5 & 25.3 & 6.4 \\
Fine-O & 50 & 13.4 & 10.8 & 29.6 & 34.3 & 11.9 \\
Medium & 52 & 14.6 & 22.9 & 19.6 & 39.2 & 3.8 \\
Medium-O & 64 & 9.8 & 22.3 & 47.6 & 20.4 & 0.0 \\
Large & 34 & 14.0 & 4.0 & 38.7 & 31.9 & 13.2 \\
Large-O & 50 & 0.0 & 6.1 & 33.6 & 45.2 & 13.4 \\
Unsprayed control & 14 & 0.0 & 0.0 & 0.0 & 50.0 & 50.0 \\
Insecticide control & 52 & 0.0 & 0.0 & 5.5 & 30.0 & 64.5 \\
\hline
\end{tabular}

${ }^{2}$ Fruit color rating is based on the total proportion of the fruit with red color $\left(\chi^{2}=95.16 ; \mathrm{df}=7 ; P \leq 0.001\right.$, proportional-odds model).

Table 4. Phytophagous insect abundance on columnar apple trees with large insect-exclusionary cages.

\begin{tabular}{|c|c|c|c|c|c|c|}
\hline \multirow[b]{2}{*}{ Insect } & \multicolumn{4}{|c|}{ Cage pore size } & \multicolumn{2}{|c|}{ Controls } \\
\hline & Fine & Medium & Medium-O & Large & Unsprayed & Insecticide \\
\hline \multicolumn{7}{|c|}{1991} \\
\hline Spotted tentiform leafminer ${ }^{2}$ & $0.6 b^{y}$ & $0.5 \mathrm{~b}$ & $0.9 \mathrm{c}$ & $2.2 \mathrm{~d}$ & $1.8 \mathrm{~d}$ & $0.0 \mathrm{a}$ \\
\hline Lyonetia speculella ${ }^{2}$ & $0.0 \mathrm{a}$ & $0.0 \mathrm{a}$ & $0.2 \mathrm{~b}$ & $0.2 \mathrm{~b}$ & $0.6 \mathrm{c}$ & $0.0 \mathrm{a}$ \\
\hline Apple skeletonizer ${ }^{x}$ & $0.2 \mathrm{a}$ & $0.1 \mathrm{a}$ & $0.1 \mathrm{a}$ & $0.4 \mathrm{a}$ & $2.1 \mathrm{~b}$ & $0.0 \mathrm{a}$ \\
\hline Potato leafhopper & $0.1 \mathrm{~b}$ & $0.0 \mathrm{a}$ & $0.1 \mathrm{ab}$ & $0.2 \mathrm{~d}$ & $0.3 \mathrm{~d}$ & $0.2 \mathrm{c}$ \\
\hline \multicolumn{7}{|c|}{1992} \\
\hline Spotted tentiform leafminer ${ }^{2}$ & $1.6 \mathrm{~b}$ & $0.3 \mathrm{a}$ & $0.1 \mathrm{a}$ & $0.1 \mathrm{a}$ & $0.2 \mathrm{a}$ & $0.4 \mathrm{a}$ \\
\hline Apple skeletonizer ${ }^{y}$ & $0.0 \mathrm{a}$ & $0.0 \mathrm{a}$ & $0.4 \mathrm{ab}$ & $0.8 \mathrm{~b}$ & $6.9 \mathrm{~d}$ & $3.0 \mathrm{c}$ \\
\hline Potato leafhopper ${ }^{w}$ & $0.0 \mathrm{a}$ & $0.0 \mathrm{a}$ & $0.0 \mathrm{a}$ & $0.0 \mathrm{a}$ & $0.4 \mathrm{c}$ & $0.2 \mathrm{~b}$ \\
\hline
\end{tabular}

${ }^{2}$ Mean number of mines per leaf.

${ }^{y}$ Mean separation in rows by $L S D$ at $P \leq 0.05$ (for all analyses: treatment $\mathrm{df}=5$, error $\mathrm{df}=27$. Spotted tentiform leafminer 1991: $\mathrm{F}=30.97 ; 1992: \mathrm{F}=2.57 ;$ L. speculella 1991: $\mathrm{F}=7.94$; apple skeletonizer $1991: \mathrm{F}=14.25$; 1992: $\mathrm{F}=29.24$; potato leafhopper 1991: $\mathrm{F}=17.89 ; 1992: \mathrm{F}=7.39$ ). Nontransformed data presented. ${ }^{x}$ Mean number of leaves damaged per tree.

${ }^{w}$ Mean number of insects per leaf.

except for $\mathrm{Ca}$, which was below them in 1991 (Shear and Faust, 1980; Stiles and Reid, 1991). Nutrient levels appear to be related to phytophagous arthropod damage. Trees in the uncovered-unsprayed control and large-meshcovered treatments, which had lower nutrient levels, sustained the most severe arthropod damage. Trees in the insecticide and mediummesh treatments, which sustained the least arthropod damage, had higher nutrient levels. Ferree et al. (1986) reported decreased N concentrations in plants damaged by mites, while Ames et al. (1984) reported lower foliar $\mathrm{Ca}$ concentrations in trees with mite damage. Bodnar et al. (1983) showed spotted tentiform leafminer damage reduced foliar $\mathrm{Ca}$ and $\mathrm{Mg}$ concentrations. Therefore, lower nutrient levels in the large-mesh and uncovered-unsprayed control trees were likely due to removal by phytophagous arthropods.

Even though the microclimate differed among treatments, no effect on disease incidence was apparent. The only disease observed was an occasional apple scab lesion, which was effectively controlled by applications of myclobutanil.

Although branch count did not differ significantly among treatments, more lateral branching occurred than we expected. Columnar-form trees are characterized by reduced lateral branching (Fisher, 1970; Kelsey and Brown, 1992). Most branches observed during 1992 were longer than $20 \mathrm{~cm}$. The combination of the relatively vigorous MM. 106 rootstock coupled with high moisture supply in 1992 caused many buds to produce vegetative shoots. Although branches showed the strong upright growth characteristic of 'Starkspur
Compact Mac', when trees are planted inside insect-exclusionary cages or at very high densities, any branching will interfere with light penetration and fruit color. Mechanical harvesting of these trees, as discussed by Quinlan and Tobutt (1990), would also be more diffi-

Fruit bud formation is directly affected by light interception and does not occur in portions of apple trees receiving $<30 \%$ of ambient sunlight for prolonged periods (Faust, 1989; Jackson, 1980). In our study, potted trees in the small-cage study formed fruit in all cages during 1992, indicating no adverse effect of shading on fruit bud formation.

Fruit color recorded at harvest from trees in small insect-exclusionary cages appeared to be directly related to light levels (Fig. 4, Table $3)$. Optimal fruit color is achieved if radiation remains $>70 \%$ of full sunlight (Faust, 1989). The medium mesh caused the greatest light reduction and the poorest fruit color early in both seasons. All other mesh coverings reduced light intensity compared to the uncovered control, and fruit from trees grown in mesh-covered cages was greener early in the season compared to uncovered fruit. However, by the end of both growing seasons, fruit color, rated while the apples were still on the tree, was similar among all treatments. Yet, examination of harvested fruit revealed that the best-colored fruit came from treatments with the highest light levels. The small-cage experiment was established in the drive row of a source orchard, and shading from these large trees certainly contributed to reduced fruit pigmentation. All apples harvested had short stems, which kept them close to the tree trunk, cult on branched trees. resulting in most fruit having a poorly colored green side. However, new columnar genotypes produced by the apple breeding program at the New York State Agricultural Experiment Station have longer stems (unpublished), so this problem would be reduced.

Fruit firmness was the only other fruit characteristic influenced by the treatments. The uncovered-unsprayed and fine-O-mesh treatments produced the firmest fruit. Insect damage, particularly internal feeding, often results in fruit softening due to increased ethylene production (Lau, 1985). In our study, much of the early insect damage to fruit in the uncovered-unsprayed treatment appeared to cause hard scar tissue around the site of damage, resulting in firmer fruit. The small sample size, resulting from heavy fruit drop before harvest because of severe insect damage, may not accurately reflect fruit firmness in the uncaged-unsprayed control.

In summary, air and soil temperature, light, rain accumulation, and evaporation were the environmental characteristics significantly modified inside exclusionary cages. Exclusionary cages appeared to have the greatest effect on light and evaporation, which were reduced by $15 \%$ to $35 \%$ when compared to the uncovered control. Even with these environmental modifications, no negative effects on tree growth were observed. During 1992, all trees grown in exclusionary cages had longer shoots than the controls but not longer internodes. Nutrient concentrations were reduced only in the treatments where phytophagous insect damage was most severe. Only shoot elongation, when evaluated over the duration of the study, was reduced by severe foliage damage caused by insects. Fruit color was reduced in proportion to light reduction.

Lawson et al. (1994) reported that arthropod suppression obtained with some insectexclusionary cages was similar to that of insecticides. In the absence of insecticides, naturally occurring enemies provided significant control of many foliage-feeding arthropods. The results presented in this paper indicate that although the microenvironment inside insect-exclusionary cages was modified, tree growth was unaffected. These findings show that insect-exclusionary cages may provide an insecticide-free orchard environment suitable for detailed evaluations of integrated pest management thresholds, predator-prey relationships, and may be used to facilitate apple production without pesticides.

\section{Literature Cited}

Abacus Concepts. 1989. SuperANOVA. Abacus Concepts, Berkeley, Calif.

Ames, G.K., D.T. Johnson, and R.C. Rom. 1984. The effect of European red mite feeding on the fruit quality of 'Miller Sturdeespur' apple. J. Amer. Hort. Sci. 109(6):834-837.

Barden, J.A. 1977. Apple tree growth, net photosynthesis, dark respiration, and specific leaf weight as affected by continuous and intermittent shade. J. Amer. Soc. Hort. Sci. 102(4):391-394.

Bodnar, J.M., J.T.A. Proctor, J.E. Laing, and R.A. Cline. 1983. Nutrient changes in apple leaves due to the spotted tentiform leafminer. J. Amer. Soc. Hort. Sci. 108(5):685-688. 
Collyer, E. 1958. Some insectary experiments with predacious mites to determine their effect on the development of Metatetranychus ulmi (Koch) populations. Entomol. Expt. Appl. 1:138-146.

Croft, B.A. 1978. Potentials for research and implementation of integrated pest managements on deciduous tree-fruits, p. 101-115. In: E.H. Smith and D. Pimentel (eds.). Pest control strategies. Academic, New York.

Faust, M. 1989. Physiology of temperate zone fruit trees. Wiley, New York.

Ferree, D.C., F.R. Hall, and M.A. Ellis. 1986. Influence of mites and diseases on net photosynthesis of apple leaves. The regulation of photosynthesis in fruit trees, p. 56-62. In: A.N. Lakso and R. Lenz (eds.). Symp. Proc. Publ. New York State Agr. Expt. Sta., Geneva.

Fisher, D.V. 1970. Spur strains of McIntosh discovered in British Columbia, Canada. Fruit Var. Hort. Digest 24:27-32.

Hall, F.R. and D.C. Ferree. 1975. Influence of twospotted spider mite populations on photosynthesis of apple leaves. J. Econ. Entomol. 68(4):517-520.

Heinicke, D.R. 1965. The effect of natural shade on photosynthesis and light intensity in Red Delicious apple trees. J. Amer. Soc. Hort. Sci. 88:1-8.

Herbert, H. and K.H. Sanford. 1969. The influence of spray programs on the fauna of apple orchards in Nova Scotia: Apple rust mite, Vasates schlechtendali, a food source for predators. Can. Entomol. 101:62-67.

Jackson, J.E. 1980. Light interception and utilization by orchard systems. Hort. Rev. 2:208-267.

Jones, H.G. 1983. Estimation of an effective soil water potential at the root surface of transpiring plants. Plant Cell Environ. 6:671-674.

Jones, H.G., A.N. Lakso, and J.P. Syvertsen. 1985.
Physiological control of water status in temperate and subtropical fruit trees. Hort. Rev. 7:301344.

Jones, H.G., J.W. Palmer, C.R. Rom, and A.D Mackenzie. 1991. Water relations of 'Wijick McIntosh' apple trees. J. Hort. Sci. 66(3):311317.

Kelsey, D.F. and S.K. Brown. 1992. 'McIntosh Wijcik': A columnar mutation of 'McIntosh' apple proving useful in physiology and breeding research. Fruit Var. J. 46(2):83-87.

Lakso, A.N. and E.J. Seeley. 1978. Environmentally induced responses of apple tree photosynthesis. HortScience 13(6):646-650

Lau, O.L. 1985. Harvest indices for B.C. apples. British Columbia Orchardist 7(7):1A-20A.

Lawson, D.S., W.H. Reissig, J.P. Nyrop, and S.K. Brown. 1994. Management of arthropods on columnar apple trees using exclusionary cages. Crop Protection (In press.)

Layne, D.R. and J.A. Flore. 1992. Photosynthetic compensation to partial leaf area reduction in sour cherry. J. Amer. Hort. Sci. 117(2):279_ 286.

Looney, N.E. and W.D. Lane. 1984. Spur-type growth mutants of McIntosh apple: A review of their genetics, physiology and field performance. Acta Hort. 146:31-46.

McCullagh, P. 1980. Regression models for ordinal data. J. Royal Stat. Soc. Ser. B. 42(2):109-142.

Mika, A. and R. Antoszewski. 1972. Effect of leaf position and tree shape on the rate of photosynthesis in the apple tree. Photosynthetica 6(4):381386.

Priestley, C.A. 1969. Some aspects of the physiology of apple rootstock varieties under reduced illumination. Ann. Bot. 33:967-980.

Quinlan, J.D. and D.R. Tobutt. 1990. Manipulating fruit tree structure chemically and genetically for improved performance. HortScience 25:6064.

Reissig, W.H., R.W. Weires, C.G. Forshey, W.L. Roelofs, R.C. Lamb, H.S. Aldwinckle, and S.R Alm. 1984. Management of the apple maggot, Rhagoletis pomonella (Walsh) (Diptera: Tephritidae) in disease-resistant dwarf and semidwarf trees. Environ. Entomol. 13:684-690.

Robinson, T.L., E.J. Seeley, and B.H. Barritt. 1983 Effect of light environment and spur age on 'Delicious' apple fruit size and quality. J. Amer. Soc. Hort. Sci. 108(5):855-861.

Rom, C.R. 1991. Light thresholds for apple tree canopy growth and development. HortScience 26(8):989-992.

Sanford, K.H. and H.J. Herbert. 1967. The influence of spray programs on the fauna of apple orchards in Nova Scotia. Can. Entomol. 99:689-696.

SAS Institute. 1985. SAS user's guide: Statistics, version 5 ed. SAS Inst., Cary, N.C.

Schulze, E.D., O.L. Lange, M. Evenari, L. Kappen, and U. Buschbom. 1974. The role of air humidity and leaf temperature in controlling stomatal resistance of Prunus armeniaca L. Under desert conditions. I. A simulation of the daily course of stomatal resistance. Oecologia 17:159-170.

Shear, C.B. and M. Faust. 1980. Nutritional ranges in deciduous tree fruits and nuts. Hort. Rev. 2:142-163.

Stiles, W.C. and W.S. Reid. 1991. Orchard nutrition management. Cornell Coop. Ext. Bul. 219.

Syvertsen, J.P., L.G. Albrigo, and C.C. Childers 1986. Photosynthesis and water use efficiency of spider mite damaged citrus leaves. The regulation of photosynthesis in fruit trees, p. 52-56. In: A.N. Lakso and R. Lenz (eds.). Symp. Proc. Publ. New York State Agr. Expt. Sta., Geneva.

Wilkinson, L. 1989. SYSTAT: The system for statistics. SYSTAT, Evanston, Ill. 